\title{
The impact of ultraviolet photography on the sun safety awareness and behavior of skiers and snowboarders
}

\author{
Darren Lynn ${ }^{1}$, Trevor Jones ${ }^{1}$, Jacob Whitsitt ${ }^{1}$, Ritika Trikha ${ }^{2}$, Megan J Schlichte ${ }^{3}$, Chante Karimkhani ${ }^{4}$, Lindsay \\ Boyers $^{5}$, Helena Winston ${ }^{6}$, Cory A. Dunnick ${ }^{7}$, Robert P. Dellavalle *7,8 \\ ${ }^{1}$ University of Colorado School of Medicine, Aurora, CO, USA \\ ${ }^{2}$ Columbia University College of Physicians and Surgeons, New York, USA \\ ${ }^{3}$ Georgetown University School of Medicine, Washington, D.C., USA \\ ${ }^{4}$ Robert Wood Johnson Foundation Clinical Scholars Program, Yale University School of Medicine, New Haven, CT, USA \\ ${ }^{5}$ VA Connecticut Healthcare System, West Haven, CT, USA \\ ${ }^{6}$ Department of Community and Behavioral Health, Colorado School of Public Health, University of Colorado Anschutz Medical \\ Campus, Aurora, CO, USA \\ ${ }^{7}$ Department of Dermatology, University of Colorado Anschutz Medical Campus, Aurora, CO, USA \\ ${ }^{8}$ Dermatology Service, Eastern Colorado Health Care System, US Department of Veteran Affairs, Denver, CO, USA
}

Received: July 1, 2015

DOI: $10.5430 /$ jer.v2n1p9
Accepted: August 16, 2015

Online Published: September 21, 2015

URL: http://dx.doi.org/10.5430/jer.v2n1p9

\begin{abstract}
Objective: Snow sport enthusiasts, such as snowboarders and skiers, are a less studied population at significant risk for ultraviolet (UV) exposure due to long hours spent at high altitudes with more intense UV radiation. Studies have documented the efficacy of UV photography to impact sun protection habits by individuals with a range of skin cancer risk factors. Informing snow sport enthusiasts of their sun damage through UV photography may be a way to change this population's perception and behavior of sun protection.

Methods: A UV camera was utilized at the 2013 SnowSports Industries America Snow Show in Colorado to assess the level of accumulated sun damage in show attendees. A follow-up survey was performed at this same event one year later in 2014. Participants at the 2013 event were recruited to a UV camera booth and completed a ten-question pre-survey assessing baseline sun-safety awareness and behaviors. Full-face frontal photographs using two different UV camera models were then taken and shown on a digital screen to the participants. Individualized education was provided regarding the degree of sun damage revealed by the intervention as well as sun safety recommendations. Participants were at the 2013 event were then contacted via email six months later to complete a ten-question survey on surveymonkey.com. The survey assessed the permanence of the UV photography intervention on sun habits over the duration of the ski/snowboard season. Email was used for communication purposes after a poor response rate using telephone for a one-month post-intervention follow-up.

Results: The 2013 post-intervention study revealed a $41 \%$ response rate $(n=46)$ with overall positive influence of UV photography on sun protection behavior in the survey. Post-intervention survey results for the 2014 study with an observed response rate of $28 \%(\mathrm{n}=37)$ with a similar overall positive influence of our intervention on sun protection behavior.

Conclusions: UV photography-based interventions and education may impact sun-safety behavior in high-risk populations such as skiers and snowboarders that may otherwise not receive appropriate education regarding the dangers of UV exposure
\end{abstract}

\footnotetext{
* Correspondence: Robert P. Dellavalle, MD, PhD, MSPH; Email: robert.dellavalle@ucdenver.edu; Address: Department of Veteran Affairs Medical Center, 1055 Clermont Street, Box 165, Denver, CO 80220, USA.
} 
and prevention of skin cancer. However, more controlled studies should be conducted to positively associate UV photography intervention and education and sun safety behavior.

Key Words: UV photography, Sun protection, Sun behavior, UV exposure, Snow boarders, Skiers

\section{INTRODUCTION}

Over the past decade, the rate of melanoma in the United States has increased approximately $2.6 \%$ each year, accounting for over 9,000 deaths in 2013 alone. ${ }^{[1]}$ Sun exposure is a well-established risk factor for skin cancer, accounting for $90 \%$ of all incidences in the United States. ${ }^{[2]}$ The risk of skin cancer and skin damage due to these harmful ultraviolet (UV) rays can be reduced through protective behaviors such as avoiding midday sun, wearing sunscreen, using protective clothing and avoidance of artificial ultraviolet (UV exposure), such as indoor tanning beds. ${ }^{[3-6]}$ Although complete avoidance of all forms of UV exposure is ideal, it is not always possible among certain populations, namely, the skiers and snowboarders; consequently, enhancing sun exposure awareness to increase sun protection behavior is a reasonable approach for this group.

Skiers and snowboarders represent a minority of the population who are susceptible to UV radiation due to the excessive amounts of sun exposure in high altitudes as well as radiation from the atmosphere and reflected off snowy surfaces. ${ }^{[7]}$ In addition, behaviors of this population have been linked to other sun safety bahaviors seen in other research studies with similar climates, although the evidence is limited. Robinson and colleagues report that the generally less sunny and colder regions (Western and Northern United States) have individuals that may intentionally seek out sun exposure, suggesting the ski/snowboard population might also engage in similar activities. $^{[8,9]}$

Recent studies have employed UV photography as a personalized, image-based tool that allows for patient interaction and discussion of potential sun exposure risks and counseling regarding sun-protection promotion. ${ }^{[8,10-13]} \mathrm{A}$ previous study demonstrated that the UV-photography intervention has a greater impact on individuals at higher risk for melanoma. ${ }^{[1,12,14]}$ The immediate results from the UV camera reveal the structural bodily damage characteristic of poor sun protection behavior and may offer a particularly promising approach as the outcomes are often immediately comprehensible to the participant as well as concerning. ${ }^{[15]}$ There are several recent studies that describe a positive correlation between the impact of UV-induced skin damaged based on UV photograph interventions and sun protection behavior. For example, Gibbons and Mahler et al. describe a reduction in college students' intention to tan, tanning behavior, and measured skin tan (using a calorimeter) when UV photography was employed..$^{[8,13,16]}$ Most other research has identified that highlighting the connection between UV exposure and its effect on photoaging has given other (often younger) populations another reason to protect themselves from the sun. ${ }^{[10-14,16,17]}$ Taken as a whole, these findings suggest that a personalized, interactive approach, with emphasis on high-risk populations, may be an efficacious and valuable approach to skin cancer prevention and awareness in high risk groups. We hypothesize that the use of UV photography and personalized counseling encouraging sun-safe behavior to improve sun protection awareness and practices in this population will be an effective way to positively affect their behavior and perceptions of radiation damage. Specifically, we expect our intervention will change opinions or attitudes of sun-protective behavior.

\section{METHODS}

Participants were recruited in late January at the 2013 and 2014 SnowSports Industries America (SIA) Snow Show in Denver, Colorado. For both events, participants completed a ten-question survey assessing their baseline sun-safety awareness and behaviors; afterwards their picture was taken with a VISIA complexion analysis UV photography system. Each participant was shown their forehead digital photograph highlighting UV-induced skin damage (see Figure 1) and the effects of sun damage were highlighted. Recruits were then taught the importance of sun protection in the prevention of skin cancer and the types of protection available were subsequently discussed.

Six months following the initial survey, a ten question followup survey was conducted on participants to assess the impact of the UV photography-based intervention on sun safety practices during the previous winter ski/snowboard season via phone call and email for the 2013 and 2014 events, respectively. This study was approved by the Arizona Institutional Review Board, Protocol \#13-0037-00. Informed consent from the participants was obtained orally and participants were not compensated.

\section{RESULTS}

A total of 134 participants completed the initial pre-survey for both the 2013 and 2014 events. The 2013 study revealed a 
$41 \%$ response rate $(n=46)$ to phone calls whereas a response rate of $28 \%(n=37)$ was observed for the 2014 study when using email, with both studies showing an overall positive influence of UV photography on sun protection behavior. We anticipated an improved response rate using email rather than phone for follow-up communication, however this was not observed. Data from the 2014 event is compared with 2013 in Tables 1 and 2. Tables 3 and 4 show the responses to individual (pre- and post-intervention) survey questions from 2014 study participants. Responses to individual survey questions from the 2013 can be found in Tables 1 and 2. ${ }^{[18]}$ Figure 2 depicts a graphical representation to some of the behavior responses from part of the 2014 secondary survey that was not included in the 2013 study population. Interestingly, $21 \%(n=28)$ of the participants in the 2014 data set were also a part of the 2013 study, having undergone the previous intervention once before.

Table 1. Comparison of participation between the 2013 and 2014 SnowSports Industries America (SIA) Snow Shows

\begin{tabular}{lll}
\hline Year & $\mathbf{2 0 1 3}$ & $\mathbf{2 0 1 4}$ \\
\hline Total Surveyed & 112 & 134 \\
Number responded to secondary survey & 46 & 37 \\
Percent response to secondary survey & $41 \%$ & $28 \%$ \\
Previous UV photo taken & - & 28 \\
\hline
\end{tabular}

Table 2. UV camera effect on sun protection

\begin{tabular}{lll}
\hline & $\mathbf{2 0 1 3}$ & $\mathbf{2 0 1 4}$ \\
\hline Influenced opinion & $76 \%(35)$ & $73 \%(27)$ \\
Changed Behavior & $61 \%(28)$ & $68 \%(25)$ \\
Increased sunscreen use & $71 \%(33)$ & $62 \%(23)$ \\
\hline
\end{tabular}

Table 3. Pre-survey questions and answers

\begin{tabular}{|c|c|c|c|c|c|c|}
\hline $\begin{array}{l}\text { How often do you wear a helmet or hat } \\
\text { that shades your face, ears, and neck } \\
\text { when skiing or snowboarding? }\end{array}$ & $0 \%$ & $25 \%$ & $50 \%$ & $75 \%$ & $100 \%$ & \\
\hline $\mathrm{N}(\%)$ & $8(6.0)$ & $11(8.2)$ & $11(8.2)$ & $23(17.2)$ & $81(60.4)$ & \\
\hline $\begin{array}{l}\text { How often do you wear sunglasses or } \\
\text { goggles when skiing or snowboarding? }\end{array}$ & $0 \%$ & $25 \%$ & $50 \%$ & $75 \%$ & $100 \%$ & N/A \\
\hline $\mathrm{N}(\%)$ & $0(0)$ & $4(3.0)$ & $2(1.5)$ & $20(14.9)$ & $106(79.1)$ & $2(1.5)$ \\
\hline $\begin{array}{l}\text { How often do you wear sunscreen when } \\
\text { skiing or snowboarding? }\end{array}$ & $0 \%$ & $25 \%$ & $50 \%$ & $75 \%$ & $100 \%$ & \\
\hline $\mathrm{N}(\%)$ & 16 (11.9) & 25 (18.6) & 30 (22.4) & $30(22.4)$ & 33 (24.6) & \\
\hline $\begin{array}{l}\text { If you wear sunglasses or goggles, do } \\
\text { they have UV protective lenses? }\end{array}$ & Yes & No & I don't know & N/A & & \\
\hline $\mathrm{N}(\%)$ & 113 (84.3) & $4(3.0)$ & 17 (12.7) & $0(0)$ & & \\
\hline $\begin{array}{l}\text { What is the sun protection factor of the } \\
\text { sunscreen you use most often? }\end{array}$ & Less than 30 & 30 or Greater & Don't know & Don't use & N/A & \\
\hline $\mathrm{N}(\%)$ & $42(31.3)$ & $81(60.4)$ & $6(4.5)$ & $5(3.7)$ & $0(0)$ & \\
\hline $\begin{array}{l}\text { How many times did you have a peeling } \\
\text { burn last ski season (winter 2012-2013)? }\end{array}$ & 0 & 1 & 2 & $3-6$ & $>7$ & $\begin{array}{l}\text { No } \\
\text { Answer }\end{array}$ \\
\hline $\mathrm{N}(\%)$ & 87 (64.9) & 26 (19.4) & $11(8.2)$ & $7(5.2)$ & $2(1.5)$ & $1(0.07)$ \\
\hline $\begin{array}{l}\text { How many times did you have a peeling } \\
\text { burn this ski season (winter 2013-2014)? }\end{array}$ & 0 & 1 & 2 & 3-6 & $>7$ & $\begin{array}{l}\text { No } \\
\text { Answer }\end{array}$ \\
\hline $\mathrm{N}(\%)$ & $114(85.1)$ & $9(6.7)$ & $4(3.0)$ & 2 (3.) & $1(0.07)$ & $4(3.0)$ \\
\hline $\begin{array}{l}\text { How many times in your life have you } \\
\text { had a sunburn that blistered? }\end{array}$ & 0 & 1 to 5 & 6 to 10 & 11 to 15 & $>15$ & \\
\hline $\mathrm{N}(\%)$ & $23(17.2)$ & $61(45.5)$ & 25 (18.7) & $11(8.2)$ & $14(10.4)$ & \\
\hline $\begin{array}{l}\text { How would you describe your lifetime } \\
\text { level of sun exposure? }\end{array}$ & Very Low & Low-Moderate & Moderate & High & Very High & \\
\hline $\mathrm{N}(\%)$ & $4(3.0)$ & $1(0.07)$ & 36 (26.9) & $67(50)$ & $26(19.4)$ & \\
\hline
\end{tabular}


Table 4. Post-survey questions and answers

\begin{tabular}{|c|c|c|c|c|}
\hline $\begin{array}{l}\text { Did the UV-camera picture you had taken this past winter influence } \\
\text { your opinion on sun protection? }\end{array}$ & Yes & No & Neither Agree or Disagree & \\
\hline $\mathrm{N}(\%)$ & $31(83.8)$ & $3(8.1)$ & $3(8.1)$ & \\
\hline $\begin{array}{l}\text { Did the UV-camera picture you had taken this past winter influence } \\
\text { your opinion on wearing headgear (e.g. hat, helmet) that shades your } \\
\text { face? }\end{array}$ & Yes & No & Neither Agree or Disagree & \\
\hline $\mathrm{N}(\%)$ & $22(59.5)$ & $6(16.2)$ & $9(24.3)$ & \\
\hline $\begin{array}{l}\text { Did the UV-camera picture you had taken this past winter influence } \\
\text { your opinion on wearing eye protection (e.g. sunglasses, goggles)? }\end{array}$ & Yes & No & Neither Agree or Disagree & \\
\hline $\mathrm{N}(\%)$ & $25(67.6)$ & 7 (18.9) & $5(13.5)$ & \\
\hline $\begin{array}{l}\text { Did the UV-camera picture you had taken this past winter influence } \\
\text { your opinion on using sunscreen? }\end{array}$ & Yes & No & Neither Agree or Disagree & \\
\hline $\mathrm{N}(\%)$ & $31(83.8)$ & $4(10.8)$ & $2(5.4)$ & \\
\hline $\begin{array}{l}\text { Did the UV-camera picture you had taken this past winter influence } \\
\text { your opinion on wearing a higher SPF sunscreen? }\end{array}$ & Yes & No & Neither Agree or Disagree & \\
\hline $\mathrm{N}(\%)$ & $24(64.9)$ & 7 (18.9) & $6(16.2)$ & \\
\hline $\begin{array}{l}\text { Did the UV-camera picture you had taken this past winter influence } \\
\text { your opinion on reapplying sunscreen during the day? }\end{array}$ & Yes & No & Neither Agree or Disagree & \\
\hline $\mathrm{N}(\%)$ & $25(67.6)$ & $8(21.6)$ & $4(10.8)$ & \\
\hline $\begin{array}{l}\text { Did the UV-camera picture you had taken influence your behavior on } \\
\text { sun protection? }\end{array}$ & Yes & No & Neither Agree or Disagree & \\
\hline $\mathrm{N}(\%)$ & $27(73.0)$ & $5(13.5)$ & $8(21.6)$ & \\
\hline $\begin{array}{l}\text { Did the UV-camera picture you had taken influence your behavior on } \\
\text { wearing headgear (e.g. hate, helmet) that shades your face? }\end{array}$ & Yes & No & Neither Agree or Disagree & \\
\hline $\mathrm{N}(\%)$ & $18(48.6)$ & $10(27.0)$ & 9 (24.3) & \\
\hline $\begin{array}{l}\text { Did the UV-camera picture you had taken influence your behavior on } \\
\text { wearing eye protection (e.g. sunglasses, goggles)? }\end{array}$ & Yes & No & Neither Agree or Disagree & \\
\hline $\mathrm{N}(\%)$ & $20(54.0)$ & $9(24.3)$ & $8(21.6)$ & \\
\hline $\begin{array}{l}\text { Did the UV-camera picture you had taken influence your behavior on } \\
\text { using sunscreen? }\end{array}$ & Yes & No & Neither Agree or Disagree & \\
\hline $\mathrm{N}(\%)$ & $24(64.9)$ & $8(21.6)$ & $5(13.5)$ & \\
\hline $\begin{array}{l}\text { Did the UV-camera picture you had taken influence your behavior on } \\
\text { wearing a higher SPF sunscreen? }\end{array}$ & Yes & No & Neither Agree or Disagree & \\
\hline $\mathrm{N}(\%)$ & $18(48.6)$ & $10(27.0)$ & $9(24.3)$ & \\
\hline $\begin{array}{l}\text { Did the UV-camera picture you had taken influence your behavior on } \\
\text { reapplying sunscreen during the day? }\end{array}$ & Yes & No & Neither Agree or Disagree & \\
\hline $\mathrm{N}(\%)$ & $22(59.5)$ & $9(24.3)$ & $6(16.2)$ & \\
\hline $\begin{array}{l}\text { After getting the UV-camera picture taken, do you think you should } \\
\text { get more sun exposure, less sun exposure, or no change? }\end{array}$ & $\begin{array}{l}\text { More Sun } \\
\text { Exposure }\end{array}$ & $\begin{array}{l}\text { Less Sun } \\
\text { Exposure }\end{array}$ & $\begin{array}{l}\text { The UV photo did not } \\
\text { influence my opinion }\end{array}$ & \\
\hline $\mathrm{N}(\%)$ & $0(0)$ & $27(73.0)$ & $10(27.0)$ & \\
\hline $\begin{array}{l}\text { After having the UV-camera picture taken, do you think you should } \\
\text { get more sun exposure, less sun exposure, or no change? }\end{array}$ & $\begin{array}{l}\text { More Sun } \\
\text { Exposure }\end{array}$ & $\begin{array}{l}\text { Less Sun } \\
\text { Exposure }\end{array}$ & $\begin{array}{l}\text { The UV photo did not } \\
\text { influence my opinion }\end{array}$ & \\
\hline $\mathrm{N}(\%)$ & $4(10.8)$ & $18(48.6)$ & $15(40.5)$ & \\
\hline $\begin{array}{l}\text { Did the UV-camera picture cause you to be concerned about skin } \\
\text { cancer, aging effects or sun exposure, both, or neither? }\end{array}$ & Skin cancer & Aging & Both & Neither \\
\hline $\mathrm{N}(\%)$ & $4(10.8)$ & $6(16.2)$ & $23(62.2)$ & $4(10.8)$ \\
\hline $\begin{array}{l}\text { How many peeling sunburns over a lifetime are associated with an } \\
\text { increased risk of skin cancer? }\end{array}$ & 0 to 2 & 3 to 5 & I don't know & \\
\hline $\mathrm{N}(\%)$ & 9 (24.3) & 11 (29.7) & 17 (45.9) & \\
\hline $\begin{array}{l}\text { Assume you are wearing the same clothes on and off the slopes. If } \\
\text { you are skiing or snowboarding on a cold, bright day, how likely are } \\
\text { you to get a sunburn with snow on the ground? }\end{array}$ & More likely & Less Likely & Equally Likely & \\
\hline $\mathrm{N}(\%)$ & 35 (94.6) & $0(0)$ & $2(5.4)$ & \\
\hline $\begin{array}{l}\text { Assume you are wearing the same clothes on and off the slopes, if } \\
\text { you are skiing or snowboarding on a cold, bright day, how likely are } \\
\text { you to get a sunburn without snow on the ground? }\end{array}$ & More likely & Less Likely & Equally Likely & \\
\hline $\mathrm{N}(\%)$ & 4 & 23 & $11(29.7)$ & \\
\hline
\end{tabular}




\section{Discussion}

Our study indicates the potential impact of UV photographybased interventions among high-risk populations who avidly participate in snow sports; however, our data is limited by not having a control group. Although the use of email in 2014 for follow-up communication did not show a greater response rate than the phone method used in 2013, both studies indicated a similar positive effect of UV photography based intervention on sun protection and behavior. This shows UV photography may have a reliable impact on sun protective behavior, shown by behavior change in both studies. As seen in Figure 1, UV photography has the potential to influence the opinions of skiers and snowboarders concerning sun protection behaviors and practices; however, it is notable that the self-reported changes in behavior were not quite as robust, as previously hypothesized.

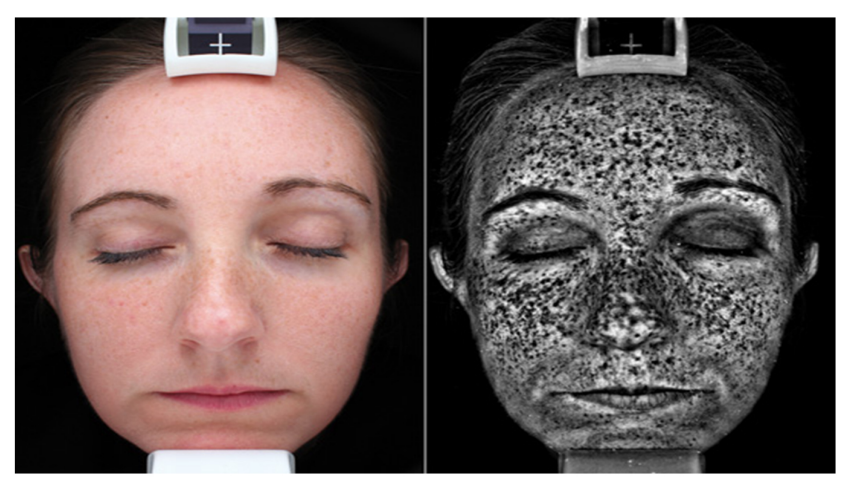

Figure 1. Example of before UV camera exposure (left) compared to UV camera photo (right) highlighting UV damage. UV light is attenuated by melanin which UV photography is able to capture and display, correlating to areas of chronically sun damaged skin. Image courtesy of Courtesy of Canfield Imaging systems and VISIA complexion analysis.

The difference in secondary survey responses of the 2013 participants distinguishing "opinion" vs. "behavior" of sun protection prompted an addendum to the 2014 post-survey that further analyzed this difference. Interestingly, all inquiries regarding sun protection dropped at least $10 \%$ among positive responses between questions about opinion to actual behavioral incorporation (see Figure 2). This observation suggests UV camera photography used to elucidate sun-induced skin damage may not be an effective method in changing the behavior of a certain portion of the population. Additional approaches, such as showing sun-induced age lines and wrinkles, may be a way to circumvent the behavioral drop seen in this population.

Published by Sciedu Press

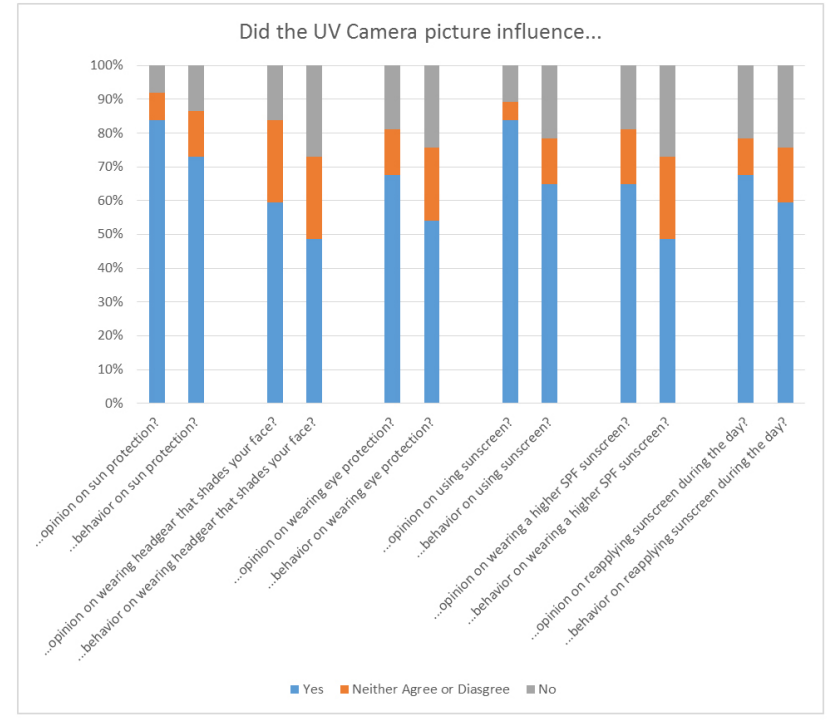

Figure 2. Graphical representation of the self-reported changes in opinion versus behavioral effects as given by participants in the post-UV camera survey for $2014(n=37)$. This survey was not included in the 2013 study population.

We hypothesized that participants whose photographs appeared to show more severe photo damage would be likely to have a more significant immediate reaction to viewing their photograph, and a higher rate of sun-protective behavior response. Thus, possible areas for future investigation include correlating the degree of sun damage in UV photographs with the extent of opinion and behavior change to determine whether this intervention has more impact on those with more sun damage and at higher risk. Further, the duration of impact of the intervention is also unknown and could be determined by following a cohort for a longer period of time following the intervention. Barriers to the use of UV photography as a prevention strategy for melanoma include a current lack of reimbursement for providing this service and a lack of public knowledge of its utility. In conclusion, UV photography-based interventions have the potential to impact sun-safe behavior or attitude, particularly in high-risk populations such as skiers and snowboarders that may otherwise not receive appropriate education regarding the dangers of UV exposure and prevention of skin cancer. However, in order to fully elucidate UV photography's impact and benefit on this population, a more controlled studies with a larger sample population should be done.

\section{Limitations}

The current study was limited by the lack of assessment for individual participants' melanoma risk factors or skin type. Further, no control group was used due to lack of participa- 
tion. This weakened our study, limiting our ability to make statistically significant conclusions.

\section{ACKNOWLEDgements}

Please acknowledge anyone who contributed towards the study by making substantial contributions to conception, design, acquisition of data, or analysis and interpretation of data, or who was involved in drafting the manuscript or revising it critically for important intellectual content, but who does not meet the criteria for authorship.

\section{REFERENCES}

[1] Institute NC. Surveillance, epidemiology, and end results programs: Turning cancer data into discovery 2012 [cited 2015 June 23] Available from: http://seer.cancer.gov/statfacts/html/m elan.html

[2] Koh HK, Geller AC, Miller DR, et al. Prevention and early detection strategies for melanoma and skin cancer. Current status. Arch Dermatol. 1996; 132(4): 436-43. Epub 1996/04/01. PMid:8629848. http: //dx.doi.org/10.1001/archderm.1996.03890280098014

[3] Foundation SC. Skin cancer facts [cited 2015 June 23]. Available from: http://www.skincancer.org/skin-cancer-facts/

[4] Naylor MF, Farmer KC. The case for sunscreens. A review of their use in preventing actinic damage and neoplasia. Arch Dermatol. 1997; 133(9): 1146-54. Epub 1997/09/25. PMid:9301593. http: //dx.doi.org/10.1001/archderm.1997.03890450096012

[5] Dummer R, Maier T. UV protection and skin cancer. Recent Results Cancer Res. 2002; 160: 7-12. Epub 2002/06/25. PMid:12079240. http://dx.doi.org/10.1007/978-3-642-59410-6_2

[6] Foundation SC. Melanoma prevention guidelines 2015 [cited 2015 June 23]. Available from: http://www.skincancer.org/ski $\mathrm{n}$-cancer-information/melanoma/melanoma-preventio $\mathrm{n}$-guidelines

[7] Andersen PA, Buller DB, Walkosz BJ, et al. Environmental cues to UV radiation and personal sun protection in outdoor winter recreation. Arch Dermatol. 2010; 146(11): 1241-7. Epub 2010/11/17. PMid:21079060. http://dx.doi.org/10.1001/archdermato 1.2010.327

[8] Mahler HI, Kulik JA, Gerrard M, et al. Effects of photoaging information and UV photo on sun protection intentions and behaviours: a cross-regional comparison. Psychol Health. 2013; 28(9): 1009-31. Epub 2013/03/30. PMid:23537173. http://dx.doi.org/10.10 $80 / 08870446.2013 .777966$

[9] Robinson JK, Rigel DS, Amonette RA. Trends in sun exposure knowledge, attitudes, and behaviors: 1986 to 1996. J Am Acad Dermatol. 1997; 37(2 Pt 1): 179-86. Epub 1997/08/01. PMid:9270501.

[10] Mahler HI, Kulik JA, Gerrard M, et al. Long-term effects of appearance-based interventions on sun protection behaviors. Health
Psychol. 2007; 26(3): 350-60. Epub 2007/05/16. PMid:17500622. http://dx.doi.org/10.1037/0278-6133.26.3.350

[11] Mahler HI, Kulik JA, Gerrard M, et al. Effects of upward and downward social comparison information on the efficacy of an appearance-based sun protection intervention: a randomized, controlled experiment. J Behav Med. 2010; 33(6): 496-507. Epub 2010/07/24. PMid:20652391. http://dx.doi.org/10.1007/s 10865-010-9279-3

[12] Gamble RG, Asdigian NL, Aalborg J, et al. Sun damage in ultraviolet photographs correlates with phenotypic melanoma risk factors in 12-year-old children. J Am Acad Dermatol. 2012; 67(4): 587-97. Epub 2012/03/13. PMid:22406230. http://dx.doi.org/10.10 $16 / \mathrm{j} \cdot \mathrm{jaad} .2011 .11 .922$

[13] Gibbons FX, Gerrard M, Lane DJ, et al. Using UV photography to reduce use of tanning booths: a test of cognitive mediation. Health Psychol. 2005; 24(4): 358-63. Epub 2005/07/28. PMid:16045371. http://dx.doi.org/10.1037/0278-6133.24.4.358

[14] Madera P, Buendia-Eisman A, Olmo FJ, et al. [Melanoma, altitude, and UV-B radiation]. Actas Dermosifiliogr. 2011; 102(3): 199-205. Epub 2011/02/22. PMid:21334587. http://dx.doi.org/10.10 $16 / \mathrm{j} . \mathrm{ad} .2010 .08 .003$

[15] Hollands GJ, Hankins M, Marteau TM. Visual feedback of individuals' medical imaging results for changing health behaviour. Cochrane Database Syst Rev. 2010(1): Cd007434. Epub 2010/01/22. PMid:20091633. http://dx.doi.org/10.1002/14651858.CD 007434 . pub2

[16] Mahler HI, Kulik JA, Harrell J, et al. Effects of UV photographs, photoaging information, and use of sunless tanning lotion on sun protection behaviors. Arch Dermatol. 2005; 141(3): 373-80. Epub 2005/03/23. PMid:15781679. http://dx.doi.org/10.1001/a rchderm.141.3.373

[17] Pagoto S, McChargue D, Fuqua RW. Effects of a multicomponent intervention on motivation and sun protection behaviors among midwestern beachgoers. Health Psychol. 2003; 22(4): 429-33. Epub 2003/08/28. PMid:12940400. http://dx.doi.org/10.1037/0 278-6133.22.4.429

[18] Jones T, Baceviciene R, Vukmer T, et al. Impact of Ultraviolet Photography on Sun Safety Practice of Snow Sport Industry Conference Attendees. The Open Dermatology Journal. 2014. 